\title{
THE IMAGE OF WOMEN IN HANINDAWAN'S LAMPOE PLENTHONG 15 WATT DRAMA SCRIPT
}

\author{
Tian Setyanto, Andayani, Nugraheni Eko Wardani \\ Pendidikan Bahasa dan Sastra Daerah, Pascasarjana Universitas Sebelas Maret, Indonesia \\ Jalan Ir. Sutami 36A, Kentingan, Jebres, Surakarta, Indonesia \\ Corresponding Author: tiansetyanto@student.uns.ac.id
}

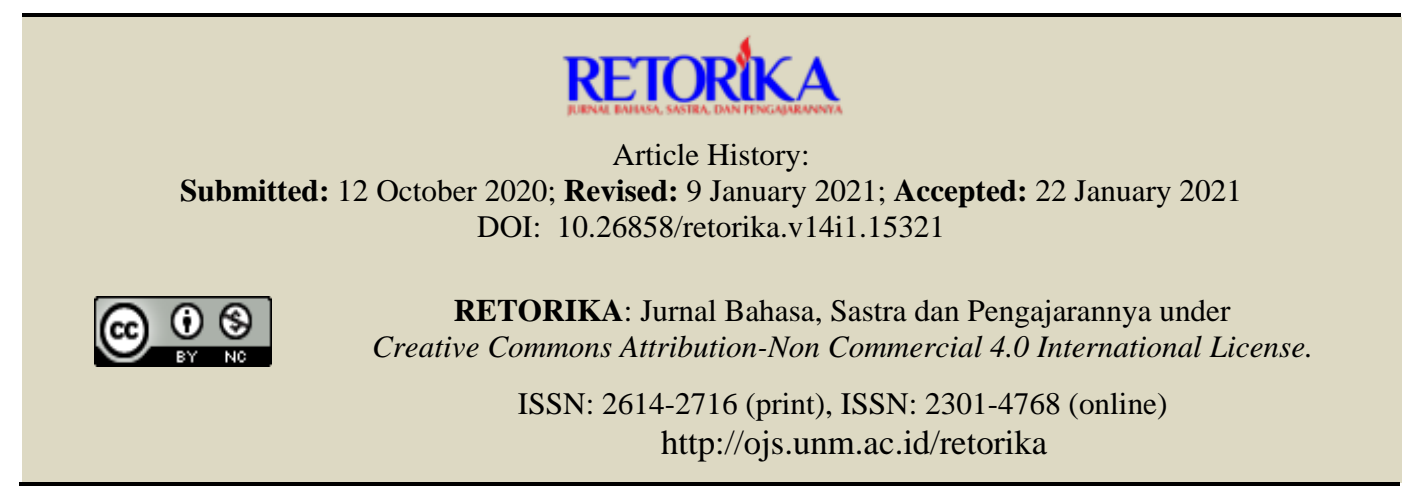

\begin{abstract}
The purpose of this research was to describe the image of women in Hanindawan's drama script Lampoe Plenthong 15 Watt. This research was a descriptive qualitative research with content analysis. The data was from Hanindawan's Lampoe Plenthong 15 Watt drama script. Data collection techniques used library techniques, listen and take notes. The data analysis technique used an interactive technique with a stylistic approach. Based on the results of the research, it was found that the form of women's image included the role of women as individuals, the role of women as mothers, the role of women as wives, the role of women as workers and the role of women in community life.
\end{abstract}

Keywords: Feminism, image of woman, Lampoe Plenthong 15 Watt, drama Scripts

Drama is a story designed with a foundation of conflict that refers to human life and then applied in the form of dialogue between characters and then performed in front of the general public (Pratiwi and Siswiyanti, 2017: 14). Traditional Javanese drama art represents the social life of the people with a cultural background (Setyawan and Saddhono, 2019: 32). A literary work, especially drama, the role of the author always describes what events he experiences in people's lives, especially in everyday life (Irma, 2018: 15).

Manuscripts from Hanindawan are texts that often raise problems about life in society, including problems faced by women. It refers to the social and cultural background of the author being very instrumental and in shaping the colors, ideologies, works, social conflicts highlighted by an author (Setyawan, Saddhono, and Rakhmawati, 2017: 150). According to Kurniawan, Suyitno and Rakhmawati (2020: 300) the Javanese drama tells a story that refers to real life, which is more about everyday problems, the conflicts that arise are more social problems.

Hanindawan is a leading theater artist from Surakarta, Central Java. He has been pursuing the arts, especially theater since 1977. His works include Pedati di Tembangan, Dag Dig Dug Dor, Wabah, Lampoe Plenthong 15 Watt etc. This Lampoe Plenthong 15 Watt manuscript was once 
a favorite script in a student theater competition which reached the provincial level in 2016. The artistic background inherent in Hanindawan makes artists who are totality in each of his works. Manuscripts from Hanindawan are texts that often raise problems about life in society, including problems faced by women.

Feminism is a movement to fight for women's rights and interests. The emergence of feminism is influenced by women who are victims of arbitrariness, this is stated by Andrea Dworkin (Ruthven, 1990: 6) to end male domination by means of destroying structures that have been formed and cultured from generation to generation as well as all forms of law which makes a woman a weak and easy being to be bullied.

According to Wolf (1999: 139) that feminism is a theory to express a woman's self-esteem so that it is not underestimated and has the same position as men. This term becomes feminist which is translated as "being human". Thus, feminism makes a woman who is confident in her abilities. Because they are often numbered with the assumption that they are universally different from men, not only biologically but also socially and culturally. The form of injustice from Fakih's opinion (2007: 78) is from the marginality of women, subordination, stereotypes, violence, workload and the socialization of gender role values ideology. According to Yahya (2016: 40) feminism makes women with all their strength and power able to get out of pressure in order to achieve gender justice and equality by bringing positive images from within these women.

The image of women is the role played by women in running the wheel of life. It is true that some women are more family oriented, for example taking on the role of a wife and the role of a mother. Then the role that is oriented in society is being a woman in general and the role of women as workers according to Sukri and Sofwan (2001: 89-91).

According to Wolf (1999: 204), women have the freedom to determine their own destiny and path. Other people also do not have the obligation to determine the choice of a woman's life path. The choices were categorized as expressions of existence which were the decisions he made in his life.
The female character in the drama script of has a desire to actualize herself according to the world she chooses. In the context of the reader, the researcher uses the concept of being a woman (images of women), which is the image of woman in the work of this manuscript showing female characters who are shackled by the dominating patriarchal culture. According to (Ruthven, 1990: 70) images of women as a sociofeminism approach which is a type of sociology that reveals the role of women.

In this study, the drama script of Hanindawan's Lampoe Plenthong 15 Watt is explored from the side of the image of women. The female characters in the drama script of Lampoe Plenthong 15 Watt are not limited in their space. It is because women can also do things that are usually done by men. The findings of this research are to uncover the side of the image of women which does not only reveal the image of women from a physical and psychological side but from the role of women themselves in running life. From Juanda \& Azis's research (2018: 7182 ), the image of women is only seen from the physical and psychological aspects of women in the story, but the image of women can be seen from the role of women in literary works.

According to Djajanegara (2000: 4) feminism is a movement in which the movement is centered on women's struggles and places on their existence. However, feminism is not necessarily about women's struggles but feminism also portrays a woman's figure, where that woman's figure can provide inspiration. In literary works, the female figure in the image of a woman provides its own value to the reader not only as a struggle but to provide a figure who can inspire for being better. The role in the family is that women play their roles as a wife and a mother. Then in society life becomes a woman in general and becomes a worker (Fakih, 2007: 78).

This is in accordance with the opinion of Tong (2010: 140) which states that Socialist Marxist feminists reject the limitation of women's movement and think that what makes us human is that we produce our way of living. So that what women can do with what men can do has the same rights and competitiveness without discrimination. Based on this background, this study will analyze and discuss the shape of the image of women in drama scripts. 


\section{METHOD}

This research was qualitative descriptive research by using literature study analysis and not tied to the place of research. This study used qualitative research which can produce descriptive data in the form of written words either from the spoken word of the informants or from the behavior observed by the researcher (Moleong, 2017: 5). The main focus in this research is to describe and explain in depth about the image of women in the drama script Lampoe Plenthong 15 Watt. This study used primary data, namely the Lampoe Plenthong 15 Watt drama script and the Lampoe Plenthong 15 Watt drama staging video. Then another data source was the writer of the script, namely Hanindawan. The drama script of Lampoe Plenthong 15 Watt and the playwright of Lampoe Plenthong 15 Watt were the main data sources in this study.

Descriptive research in case studies leads to detailed descriptions and in-depth portraits of what has actually happened in the field of study (Sutopo, 2006: 111). Data collection techniques used literature study techniques and in-depth interviews with resource persons. The literature study technique was to analyze the Lampoe Plenthong 15 Watt drama script, and observe the Lampoe Plenthong 15 Watt drama staging video. To get more detailed results, an in-depth interview was also conducted with the resource person, namely the script maker. By interviewing Hanindawan as the writer of the Lampoe Plenthong 15 Watt, more detailed results will be obtained.

The analysis technique was combined with a stylistic approach. Namely is analyzing the use of language at the level of words, phrases and sentences that refer to the meaning as the image of women contained in the drama script. Then test the validity of the data used data triangulation techniques and theory triangulation by examining the data that presented in the form of a drama script of Lampoe Plenthong 15 Watt and the theory of feminism approach to female image.

Furthermore, at the data analysis stage using a braided technique flow model of analysis where the interactive analysis is the stages of data reduction, data presentation and conclusion drawing (Miles \& Huberman, 2009: 18). In the data reduction stage, data collection was in the form of Lampoe Plenthong 15 Watt drama script and a script writer interview transcript. Then the data presentation was the result of drama script analysis and was strengthened by interviews with drama script writers to get accurate analysis results. Drawing conclusions from the results of this study.

\section{FINDINGS AND DISCUSSION}

\section{Findings}

The presentation of the results of this study describes the roles of women into five, namely (1) an individual (2) a mother in the family, (3) a wife in the family, (4) a worker, (5) a member of the community, these are described as follows.

\section{Role of Women as Individuals}

Women are creatures who have the freedom to determine the path of their choice and their own destiny. Women's choices can be categorized as expressions of existence, are decisions about choices made to show their existence.

The female character in the script in the drama script Lampoe Plenthong 15 Watt has a desire to provide self-actualization in accordance with the demands carried. This can be seen in the following quote:

\begin{abstract}
346 ICIK:
Banjur kula seneng marang wong lanang sing gadhah pangarep-arep? Pak Saimun niku pun sepuh, ampun nyumet geni wonten omah kula. Kula niki mboten wanita lemer. Dede wanita ingkang gampil dipun bayar. (LPW manuscript p. 39)
\end{abstract}

Translate:

346 ICIK:

Then I turned to the man who had hope? Mr. Saimun is old, don't make a fire in my house. I am not an easy woman. Not a cheap woman who can be easily bribed or bought.

From this quote, it is known that the Icik character shows the role of women as individuals. the characters in the script indicate the path he takes of his own choosing. This shows the attitude of a woman who is firm in looking for decisions. The woman described in the dialogue quotation does not want to be a woman who easily turns to other people. That women have a path that they take, women also have idealistic thoughts and life choices in accordance with what they expect. Even though the choice is difficult, if you are firm 
in your choice and able to carry out the consequences that you have received, it will be easy to live with.

\section{Role of Women as Mother}

Women are creatures of the almighty who have a role as growers of affection in the family. A mother is the first teacher for her children who educates and cares for her from childhood to adulthood. It is not uncommon for a mother to carry out a very difficult task which has to create a conducive psychological climate in the family. Provides a sense of comfort, serenity, peace and well-being. Compassion for all family members is her greatest dedication so that the family becomes whole.

This role of women as mothers provides a separate image in the drama script of Lampoe Plenthong 15 Watt where there is Icik character of a mother can be seen in the following quote:

O89 ICIK:

Mas! Aja meneh sewengi ora bisa mangan, paribasan seminggu awakdhewe ora bisa mangan ora apa-apa, sing penting anake dhewe sing ning Jogya karo ning Malang bisa lancar sekolahe. Suk mben dheweke ben dadi uwong, ora kaya awak dhewe. (LPW manuscript p. 11)

Translate:

089 ICIK:

Mas! Never mind that only all the night we couldn't eat, like a week we couldn't eat it was okay, as long as our children in Jogya and those in Malang can go to school smoothly. Later they will be people, not like us.

From this quote, Icik is a mother who wants her child to continue her studies. The attitude she took to give up what she was experiencing, it is better for her not to eat because she wants her child to survive outside the city because continuing his studies in university. Icik's attitude is a self-sacrificing attitude, a selfsacrificing attitude that is done by a mother for the happiness of her child. Self-sacrifice is a reflection of the role of a mother.

Not only is the self-sacrificing attitude in the above quote it also shows a mother so that her children do not have the same fate as what was experienced, this is shown by suk mben dheweke ben dadi uwong, ora kaya awakedhewe that is a sentence of hope where a mother really hopes for her child to be more successful and succeed beyond their parents and not live hard. The role of a mother is to always wish her children the best so they can be successful and succeed and realize their dreams. Furthermore, the role of mother can be seen in the following quote.

\begin{abstract}
378 ICIK:
Ben ngrasakne bungahe awakdhewe. Sing angel-angel ben awakdhewe sing ngrampungi, ora perlu didum ning dheweke kabeh lantaran sambat. Sing penak-penak lagi diwenehke ben kabeh ngrasa luwih apik. (LPW manuscript p. 43)
\end{abstract}

Translate:

378 ICIK:

Let us feel our happiness. We don't have to share it with them with sighs or lamentations that we have trouble resolving ourselves. Then we share it with them so that they are better.

From the quote of the manuscript, Icik is a mother where the role of a mother is always to motivate and provide positive encouragement. The role of mothers in the family is not only in kitchen matters but provides happiness in the family, by providing positive motivation, happiness in the family will be achieved. Icik who never complains and complains does not show that being sad for family members shows that the family does need positive encouragement from a mother even though the encouragement is only a smile that will make other family members happy and motivated.

The role of a mother in the family as a motivator in the family as well as as a protector of the family. Mothers who give a sense of comfort and serenity in the house give their own color so that each family member can feel comfortable in a mother's love. Furthermore, the role of motherhood can be seen in the following quote:

380 ICIK:

Gusti Allah kuwi Maha Linuwih. Piyambake bakal maringi sacara gratis dinggo awakdhewe, lan aku isih kerep donga, muga berkah cahya-Ne tansah tumiba ana ing omahe dhewe. Cahya limalas watt yen ning tangan-Ne wis cukup dinggo urip!

(LPW manuscript p. 43) 
Translate:

380 ICIK:

Gusti Allah is Most Cheap. He always gives free for us, and I still always pray, may His light stay burning in our homes. Fifteen watts of light when from His hand is enough to live!

From the quote from the dialogue, where Icik's role is a mother who always prays to God to be given enough fortune for her family. Icik who hangs her hopes on her God has become the duty of every religious community to continue praying and begging to always be given directions so that there are no misdirection and goals. Icik who begged to be given a lawful fortune for a blessed life.

The quote also shows that the role of a religious mother who prays and worships God to be given abundant blessings and doesn't forget to continue to be grateful for the pleasures given by God. As human beings, it is our duty to thank God Almighty for what has been given so that peace will be achieved in family life.

\section{The Role of Women as a Wife}

Humans are God's creatures that are created in pairs. Humans were created in pairs between male and female. In pairs, humans lead their lives to live in households. In modern society, husband and wife household both carry out their respective roles. So it is not only a husband who has the obligation to uphold the household, but also the wife has the same obligation to uphold the household. Women are able to be independent where a wife chooses not to depend on her husband for her life. One way for women not to depend their lives on men is by having their own income.

This role of women as wives provides its own image in the drama script of Lampoe Plenthong 15 Watt where there are characters that can be seen in the following quote:

\section{BU ANGGREK:}

Mas, mengko nek bali omah mesthi pangling. Saiki omah wis kebak tanduran kembang, omah wis kebak pengangenangen. Aku yakin, ambune kembang ning omah iki, mabur nyebrangi pulo-pulo, segara, sumebyak ngebaki papan pegaweyane, gawe wewangi ning kasurmu. My honey, sugeng dalu, love you! (NGUNCALNE ANGGREKE)

\section{(LPW manuscript p. 4)}

Translate:

023 BU ANGGREK:

Mas, when you go home, you will definitely hang around. Now this house is full of flowers, a house full of hope. I'm sure the smell of flowers in this house, flying across island after island, sea and straits, fragrantly filled his office, scented your bed. My honey, sugeng dalu, love you! (THROWING OUT HER ORCHID HANDLE)

From this quote, it is known that Mrs. Anggrek always cares for her own house with great affection. by decorating a house full of flowers to make the fragrance of flowers unique in the house. The role of women as wives is shown in the character Bu Anggrek who manages the house alone shows an independent attitude even though her husband is left to work outside the city, Mrs. Anggrek continues to carry out her duties as a wife to care for the house with great affection.

Mrs. Anggrek's task in becoming a wife is tough, even though her husband leaves her to work outside the city, Mrs. Anggrek still doesn't want to look at other men. Her loyal attitude towards her husband is shown in her waiting with great love. This is what makes Mrs. Anggrek have a strong attitude towards her husband. It is an obligation as a wife to look after and maintain the household with loyalty to our partner. Furthermore, the role of women as a wife can be seen in the following quote.

\section{PROLOG}

Soroting lampoe plenthong 15 watt ning omah Icik murub alon-alon. Lan ning kana katon Icik lagi masak sega goreng, sing ambune ngebaki papan panggonan uwong sing nonton. Ben Lantip bojone Icik ngadeg kaya satpam, nyawang Icik sing lagi masak. Wong loro kuwi ora padha guneman. Sakwise masakanne wis mateng, lantip nyurung ubarampe masak, banjur di dum ning tanggane. Icik njikuk kendhi sing kat mau esuk wis ana ning ngarep omahe.

(LPW manuscript p. 1)

Translate:

PROLOG

The Plenthong Lamp 15 Watt in Icik's house lights up slowly. And there Icik was seen cooking fried rice, whose aroma filled the audience room. Ben Lantip, icik's husband 
stood tall like a security guard, staring at Icik who was cooking. There is no dialogue between the them. When the dish was cooked, Lantip pushed all the cooking utensils, then he distributed it to several neighbors. Icik took a pitcher that had been installed in front of his house since morning.

From this quote, it is known that Icik is cooking and preparing food for his family. This is the role of women as a wife as a daily basis, namely cooking and preparing food for all family members. Indeed, it cannot be denied that the duty of a wife in terms of kanca wingking is to remain productive in kitchen matters. Some people do see the kitchen as an easy job, but if look closely, kitchen affairs are the heart of the household because kitchen affairs affect all family members. If the role of the wife does not interfere in kitchen matters, there will be hunger and conflict in the household.

This is so strong the role of a wife in kitchen affairs because it becomes the center of the family. Furthermore, the role of women as a wife can be seen in the following quote.

\section{ICIK: \\ Aku ora bakal wedi yen ta aku bener. Mas Lantip kudune ngerti. Omahe awakdhewe iki cilik, aja malah dicilikne meneh nganggo pikirane mas Lantip sing ora Lantip! Senengane ira-ira, lan ira-irane marakne anyel. \\ (LPW manuscript p. 29) \\ Translate: \\ 257 ICIK: \\ I won't be afraid as long as I'm right. Mas Lantip actually had to know. Our house is narrow, don't even get narrowed down again with Lantip's thoughts that don't lantip-lantip! Like to guess, and his guess provokes emotion.}

From this quote, the character Icik is arguing with her husband Lantip. Icik who is a wife where the role of a wife is not only a kitchen matter but also a reminder. Where a wife also gives advice and reminds her husband when he makes a mistake. Not only giving advice to husbands, but the role of a wife is also giving and reminding other family members when they make mistakes. So the role of a wife is so heavy that it is required to have wisdom in living the household life, so that the wife is also required to have broad views in order to be able to respond to problems encountered because the problems in the household are so tortuous. Furthermore, the role of women as a wife can be seen in the following quote.

334 ICIK:
(NYAUT OMONGAN) Aku durung
rampung. Ora pernah aku sambat kabeh
kuwi! Merga apa gunane awakdhewe mung
sambat? Apa yen wis sambat kahanane dadi
luwih apik? Yen awakdhewe sambat apa
bayarane awakdhewe bisa nambah? Banjur
yen sambat pajeg listrik bisa mudhun?
Wong tuwaku mbiyen ngajari urip iki
paribasan numpak kapal ning samudra.
Saya dhuwur ombake, kudu tambah
waspada, lan kudu pinter njaga kapale ben
ora kerem, lan aja lali nyawang lintang-
lintang nyawang srengenge njedul seka
ngendi lan seka ngendi angslupe, merga
kabeh kuwi dadi tengere dalan! Awakdhewe
ora cukup mung ngalahne ombak, tanpa
ngerti arep menyang ngendi
(LPW manuscript p. 38)

Translate:

334 ICIK:

(STOP SPEAKING) Wait I've not done yet. I never complained about all that! Because what if we just complain? What if we complain that things are getting better? If we complain, can we increase our income? If we wail that the electricity costs will go down? My parents used to teach that life is like riding a boat in the ocean. The higher the wave, the more vigilant you have to be, and you have to be good at shepherding your boat if you don't want to sink, and don't forget to always look at the stars to see where the sun was born and where it sets, because all of these are directions! It's not enough just to grapple with the waves, not knowing where the boat is going.

From this quote, it is known that the character Icik is arguing with her husband Lantip. Where is Icik who is telling his complaints in terms of financial management in the family. It is undeniable that the obligation to earn a living is the husband's obligation, but the wife manages to make a living so that the household needs are fulfilled. Even though the income is mediocre, the wife must be able to distribute the money according to her needs so that her needs can be 
fulfilled. Indeed, this is not easy in financial matters, it requires detailed calculations in it.

Icik characters who provide an overview of married life so that they don't give up on the situation. With the income that is still lacking, but still trying with all efforts to keep it sufficient. The optimistic attitude described by Icik is positive motivations for living the household ark. Icik who always gives hopes of a decent life to her husband who is starting to give up. This is the role of women as wives to provide motivations for husbands not to give up in all the difficulties they experience. This is very important in household life where motivation and encouragement to the husband provide positive energy in the family.

\section{Role of Women as Workers}

In this modernization era, women are required to play an active role in national development. Even if a woman is married, she still has the opportunity to develop her inner potential. This demand causes women to carry out their duties optimally. Women who have entered all lines of work, from manual labor to office jobs, have no restrictions on choosing a job. With this every woman has the freedom to choose a job.

This role of women as workers is contained in the drama script of Lampoe Plenthong 15 Watt where there are characters that can be seen in the following quote.

066 ICIK:

Mas! Wah, kowe ki ora ngewangi malah nggawe rusak! Eling, anake awake dhewe kerep ngomong: "Mak, buruh umbahumbah ora apa-apa, sing penting njaga integritas! Jaga integritas!".

(LPW manuscript p. 9)

Translate:

066 ICIK:

Mas! Wow, you do not help but instead you make it break! Remember, our children always say: "Mom, it is okay to wash laborers, as long as you take care of the integrity! keep Integrity!".

From this quote, it is known that Icik is a wash laborer. However Icik proves that a wash laborer still prioritizes professionalism. Where even though a wash laborer must maintain integrity. Integrity is an attitude that promotes honesty. Because this attitude is needed in all jobs. Job demands make Icik have a strong, professional and honest work character. Not only men, but women are also required to have the same ability as men. Furthermore, the role of women as workers can be seen in the following quote.

\section{ICIK:}

Cah lanang ora gelem ngerti rekasane bojone kok sok-sokan arep kaya polisi. Pengine nlesik-nlesik, wis dikandhani apa eneke jik nekad ora marem. Senenge takon, ning njaluk jawaban kaya sing dipikirne.

270 LANTIP:

(KARO IJIK NYAWANG BUNTELAN SANDHANGAN SING DIGAWA) Pak Zainal sing endi ya?

271 ICIK:

Yen gelem melu ngurusi kaya ngono nak mudheng kepiye angele njereng-jereng dhuwit. Apa di kira aku iki ora kesel? Apa nek disujanani ki ora lara ati?

(LPW manuscript p. 30-31)

Translate:

269 ICIK:

Men do not want to know the inconvenience of their wives, instead they act like police. I wanted to investigate, had been told what it was. She likes to ask, but asks for answers as you think.

270 LANTIP:

(WHILE STILL LOOKING AT THE PACKAGE OF CLOTHES WHICH IS BRINGING) Mr. Zainal?

271 ICIK:

If you want to take care of it like that, you know how troublesome buckets of money. Do you think I'm not tired? What if you continue to suspect you don't feel hurt?

From the quote, it can be seen that the dialogue between Icik and Lantip. Where is an Icik who has worked hard but her husband still doesn't believe in his wife's income. Indeed, a wife works when the needs of her family are still not fulfilled because she only relies on her husband's income. However, a wife is not obliged to work hard as long as her husband is around. Due to the current economic demands, wives also have to participate in making a living to fulfill their needs. This shows that the role of women as workers cannot be underestimated where women's work is not only to earn a living but still 
take care of the house so that women's work in the household seems endless.

The Icik figure illustrates to us that a wife who works hard as a laundry worker but is still suspected by her husband because she thinks that she got money not from her laundry. However, the Icik figure proves that a woman is indeed clever in making a lawful living and is good at managing family finances in order to have savings. Icik's character who gives a description of the weight of a woman at work and is still being accused by her husband, but Icik is still upholding his stance because he is telling the truth. Furthermore, the role of women as workers can be seen in the following quote.

306 ICIK:

Wong kaya awakdhewe ngene iki arep tuku beras wae ora gampang. Sampeyan wis mbuktekne dhewe, dinggo nebus dhuwit lima-las ewu wae kudu muter-muter, kepanasen njur sidane ora nggawa apaapa. Wong kaya awakdhewe ki akeh. Malah kepara ana sing mati kepidak-pidak merga antri dum-duman beras. Padha wis ora mikir nyawane dhewe, nekad suk-sukan banjur dheweke dhewe mati. Aja meneh entuk sekilo beras, golek dalan dinggo leren wae ora bisa njur ora bisa ambegan. Wong kere kuwi dinggo golek angin wae angel! (LPW manuscript p. 35)

Translate:

306 ICIK:

People like us, just buying a kilo of rice are not easy. You have proven yourself, to make up for fifteen thousand you have to go round and round, get too hot and end up carrying nothing. There are a lot of people like us. Some of them were trampled to death because of the queues for the distribution of rice. They no longer worry about their own lives, they are desperate to jostle the overlap and finally their own lives fly. Never mind getting a kilo of rice, looking for a way to pull over was unsuccessful and eventually ran out of air. It's hard for the poor to get air!

From this quote, it is known that Icik's character is not only a woman who is being crushed by the economy with a job as a laundry worker but with a very minimal income that makes Icik not give up. Icik, who said that her income as a laundry worker with an income of fifteen thousand made Icik have to rack her brains in terms of expenses. This Icik attitude clearly illustrates that the role of women as workers is indeed tough with minimal income but it does not make it easy to give up. Because everything that is done must give the best results. With the intention of praying to make Icik carry out every job sincerely.

\section{Role of Women as Community Members}

Women become members of society, which is where there is an impulse in her selves to be accepted in the community. Therefore, women are required to be able to show a positive image in social life. In social life, women must model positive behaviors. Just as the wife of an official in the community is required to provide an example of a wise and wise attitude so that the surrounding community can feel comfortable in social life.

O38 ICIK:

Mas Lannn... yen aku ngedum panganan $k i$ apa aku njaluk ijol ta? Yen pancen ora gelem ya rapapa, ora usah di pangan, wis ora di pangan ora apa-apa... enek wong ajar sedhekah kok di dhuwungi.

(LPW manuscript p. 6)

Translate:

038 ICIK:

Mas Lannn ... if I share the food, do I ask for a change? If you are not hooked, it is okay, do not have to eat it, wus is not eaten it is okay... there are people who learn to give alms, how come they are suspected.

O72 ICIK:

Yen kepengin menehi tanggane ora usah mikir murah utawa larang, merga kabeh kuwi larang. Bakso larang! Urang larang! Pitik larang! Ora ana sing murah. Urip kuwi ora murah massss... urip kuwi larang! (LPW manuscript p. 9)

Translate:

072 ICIK:

If you want to share with your neighbors, you don't have to think cheap or expensive, because everything is expensive. Meatballs are expensive! Shrimp is expensive! Chicken is expensive! Nothing is cheap. Life is not cheap beib ... life is expensive!

From this quote, it is known that the Icik figure plays her role as a member of society. In social life, we need to share, because humans are 
created as social beings. Icik who distributes food to neighbors has the goal of gluing a sense of living in harmony between communities. Even though it is not how much she shares, it can be useful. Icik characters who have the principle of the hand above are better than the lower hand, making her selves is happy in giving alms. Even though she is pressured by economic problems, she does not forget to give alms to each other so that her neighbors became harmonious and peaceful. Furthermore, the role of women in community life is shown in the dialogue quotation as follows.

\begin{abstract}
367 ICIK:
Wong-wong kae ora ngerti kepiye rasane angele urip pas-pasan apa meneh yen kekurangan. Bojone dhewe sing urip sak omah wae curiga. Saben dina takon seka ngendi dhuwite kok cukup dinggo ragad urip. Yen penjaluke kurang kuwi aja mung curiga! Tangga-tangga ya mung wanton ngomong. Dheweke kabeh ngomong yen aku iki enek sing ngeki dhuwit. Icik ki meneng-meneng nglimpe. Delikan karo wong lanang liya. Ngelokne uwong waton njeplak!

(LPW manuscript p. 42)
\end{abstract}

Translate:

367 ICIK:

Those people do not know how difficult it is to live just barely even if it is lacking. Her husband, who lives under one roof, is suspicious. Everyday they ask where the money comes from, how come it's enough to support living expenses. If you want less, don't just be suspicious! The neighbors are also talking. They said I have someone to support. Icik was quietly playing behind. Hide and seek with other men. Talk about people casually!

From these quotes, in social life the role of a woman is to provide wisdom to the surrounding community. The policy is intended so that everyone does not give bad ratings to every family. The task of women is to provide education to each local community so they are not suspicious and what negative assessments they see at first glance. Because then it will cause slander. Icik figures provide a picture for us in social life so that it is not easy to expose issues that are of course unclear. The role of women in community life is indeed a tough task because we are faced with each member of society who has a different character.

\section{Discussion}

Overall, the drama script of Lampoe Plenthong 15 Watt raises the image of women, namely the image of women as mothers, images of women as wives, images of women as workers and images of women as members of society. The findings are found in words, phrases and sentences that have meaning in the image of women in drama scripts. The results of the above explanation show that the image of women in drama scripts does not only act as weak female figures but also women can take part in jobs and in other fields that are usually done by men.

The female character in the drama script of Lampoe Plenthong 15 Watt is very influential on the story. The figure of female characters usually looks weak is not included in this script. Female characters are able to carry out tough tasks well. In fact, there are female figures who become the family's foundation by working alone even though they still have husbands, but because their husbands become unemployed, women become the people who earn a living. This proves that women can do jobs that are usually done by men.

The role of women as individuals is the life choices, she chooses in living life. Women have the right to choose the way of life. The characters in the script prove that she is not a woman who easily turns to other people. With what she has committed to her partner and will continue to live a married life.

The role of women as mothers is indeed important in the family. Indeed, it is normal for a woman to be a mother, but what distinguishes it is that being a mother is not only about caring for children but more about educating and building children's character. This task can indeed be replaced by a father, but it will be more different if a woman does it because a mother has a special bond with her child. The child who is conceived in the mother's womb for about nine months makes the bond between mother and child stronger. As well as a strong encouragement of affection that will give special attention, the mother will give the best to her child such as a self-sacrificing attitude to her child so that the child can grow and become a human being who is much better than his parents. 
Then in the role of women as wives, here the role of wives is not only taking care of the husband but also the duty of women as wives to take care of all activities at home. It is undeniable that women's work at home can be 24 hours because all matters at home are under women's authority. You can imagine if there is no female figure at home, the house will be neglected and seem messy. It is evident that the role of women as wives in managing the household cannot be underestimated.

Furthermore, the role of women as workers is a form that is contrary to the nature of women, in general because it is known that women are not found as a means of earning a living in the household. Women who earn a living to support their families are considered extraordinary women. Even though in the household earning a living is the main task of a husband, if the husband is unable to earn a living, the task of earning a living is replaced by the wife. This makes the role of women as workers become gender equality because the task of earning a living is a tough task because it requires women to work hard.

Finally, the role of women as members of society is to make women show a positive image in society. The task of women in social life requires that they always be wise and wise. Not only that, women in community life make women more sensitive to the life around them, especially the more detailed ones are their closest neighbors. Women pay more attention to the social conditions of the surrounding community. The culture of helping each other and being harmonious with neighbors can be used as a strong principle in social life. Women are indeed given feelings that are more sensitive than men, this makes women feel when a neighbor is in trouble. Not only when there is trouble, it is easier for women to share the happiness they have, even though only a few, most importantly, can feel this happiness even if a little. In the Lampoe Plenthong 15 Watt drama script, the female characters are not limited in their space. The task of the woman in the story proves that women cannot be underestimated and the task is carried out smoothly and well. So that women really cannot be underestimated, this is in accordance with the perspective of Tong's (2008: 140) opinion which rejects the limitation of women's movement, and considers that what makes us do as humans remains alive. So that what is done by men can be done by women. With this, men and women have equal rights and competitiveness without any discrimination.

In this study, it focuses on the feminist approach using the image of women, there are several studies that are relevant to research, including research by Kurniawan, Suyitno and Rakhmawati (2020: 300-306), namely the approach of feminism with female patriotism, this is in line but what distinguishes this research is about women who have a positive impact on their surroundings. The image of a woman is to give a woman a picture of her personality, not just a woman's struggle. Then according to Juanda and Azis (2018: 71-82) dividing the image of women in terms of physical and psychological. From the outside, seeing women from the physical side then from the way of thinking sees women from the female psyche. However, from this study, the image of women is not only seen from a physical and psychological point of view but also from the woman's figure. Women can be described from the way they behave, how to behave and how to look at problems. Where the role of women can have a positive impact on human life. By looking at women as figures makes the image of women more dynamic and easier to accept.

This Lampoe Plenthong 15 Watt drama script has a female character who plays an important role in the story. Even the roles played by female characters greatly influence the course of the story in the play of the script. The representation of the role of female characters in the Lampoe Plenthong 15 Watt script is manifested in the role of women as mothers, women as wives, the role of women as workers and the role of women as members of society. The study of drama scripts with a feminist approach can be used as learning in real life about gender equality and equality of women's rights. Regarding gender discrimination, which is still spreading in society, with the image of women, it can create a positive image of women so that they are not looked down on by men and so that women can be well accepted in community life. Literary research with various approaches to literary studies, especially the feminist approach, can enrich studies of literature. The goal of feminism is to increase the position and rank of women so that they are equal to that of men. One way to achieve goals is by obtaining the same 
rights and opportunities as those of men (Djajanegara, 2000: 4). So, women can play a full role in the life of society.

\section{CONCLUSION}

In this research, it is found that the image of women is not only seen from a physical and psychological perspective but also as an inspiring figure. Where the physical aspect is seen from the outside, then the psychological side is seen from the way of thinking. Reading literary works full of feminism can inspire readers to become a better person. Furthermore, feminism is not only a matter of struggle, but seen from her image, women can have a positive impact on their various roles. In terms of the role of women, they have a big share in human life.

\section{REFERENCES}

Burhanudin, M. \& Nuryatin, A. (2019). The Productivity of Literary Literacy Arena In Central Java. Proceedings of the 28th International Conference on Literature: "Literature as a Source of Wisdom, 1 (1): 867--872, doi: 10.24815/.v1i1.14829.

Djajanegara, S. (2000). Kritik Sastra Feminis: Sebuah Pengantar. Jakarta: Gramedia Pustaka Umum.

Fakih, M. (2007). Analisis Gender dan Kansfonnasi Sosial. Yogyakarta: Pustaka Pelajar.

Juanda dan Azis. (2018). Penyingkapan Citra Perempuan Cerpen Media Indonesia: Kajian Feminisme. LINGUA : Jurnal Bahasa, Sastra, dan Pengajarannya. 15 (2), 71--82.

Kurniawan., S. dan Rakhmawati, A. (2020). Javanese Women's Patriotism in The Ketoprak Manuscript "Kyai Kala Gumarang". RETORIKA: Jurnal Bahasa, Sastra dan Pengajaran, 13 (2), 300--306.

Irma, C. N. (2018). Nilai-nilai Pendidikan Karakter dalam Novel Ibuk Karya Iwan Setyawan. RETORIKA: Jurnal Bahasa, Sastra, dan Pengajarannya, 11 (1), 14--22.

Miles, M. B. \& Huberman, A.M. (2009). Analisis Data Kualitatif. Jakarta: UI-Press.

Moleong, L. J. (2017). Metode Penelitian Kualitatif. Bandung : PT. Remaja Rosdakarya Offset.

Pratiwi, Y., Siswiyanti, dan Frida. (2017). Teori Drama dan Pembelajarannya. Yogyakarta: Penerbit Ombak.
Hanindawan's drama script of Lampoe Plenthong 15 Watt has an important female character in the story. Not only that, female characters have a strong influence on the course of the story. Representation of the role of women as individuals, the role of women as mothers, the role of women as wives, the role of women as workers and the role of women in community life. The drama script of Hanindawan's Lampoe Plenthong 15 Watt has implications in society, especially in terms of gender equality and women's struggles to fight for their position in equality with the rank of men. This drama script provides an overview of the role of female characters in the realm of drama. It is hoped that this research can be used as a reference for literature review as an appreciation for gender equality.

Setyawan, B. W. dan Saddhono, K. (2019). Akulturasi Budaya Islam-Jawa dalam Pementasan Kesenian Ketoprak. Jurnal Tari, Teater, dan Wayang, 2 (1): 25--34.

Setyawan, B. W., Saddhono, K., dan Rakhmawati, A. (2017). Sociological Aspects and Local Specificity in the Classical Ketoprak Script of Surakarta Style. Journal of Language and Literature, 17 (2): 144--151.

Sukri, S. S. dan Ridin S. (2001). Perempuan dan Seksualitas dalam Tradisi Jawa. Yogyakarta: Gama Media.

Sutopo. (2006). Metode Penelitian Kualitatif. Surakarta: UNS Press.

Tong, R. P. (2010). Feminist Thought: Pengantar Paling Komprehensif kepada Aliran Utama Pemikiran Feminis. Yogyakarta: Jalasutra.

Ruthven, K. K. (1990). Feminist Literary Studies: An Introduction. New York: Cambridge University Press.

Wolf, N. (1999). Gegar Gender, Kekuasaan Perempuan Menjelang Abad 21,. Terjemahan Omi Intan Naomii dalam Eire With Fire, The New Female Power and How it Hill Chane the 21't Century. Yogyakarta: Pustaka Semesta Press.

Yahya, I. (2016). Perjuangan Perempuan Meraih Kemandirian dalam Ruang Sosial. RETORIKA: Jurnal Bahasa, Sastra dan Pengajaran, 9 (1), 40--48 